\title{
アルミナ加圧成形体における焼結時の変形の原因
}

\author{
税 安澤・張＼cjkstart躍・内田 希・植松敬三 \\ 長岡技術科学大学化学系, 940-2188 新潟県長岡市上富岡町 1603-1
}

\section{Origin of Shape Deformation during Sintering of Alumina Compacts}

\author{
Anze SHUI, Yao ZHANG , Nozomu UCHIDA and Keizo UEMATSU \\ Department of Chemistry, Nagaoka University of Technology, 1603-1, Kamitomioka-cho, Nagaoka-shi, Niigata 940-2188
}

\begin{abstract}
Alumina compacts were prepared by uniaxial pressing followed by cold isostatic pressing (CIP), and their structures were examined by both conventional and novel methods to clarify the origin of deformation during sintering. A novel liquid immersion method revealed the presence of anisotropic packing structures in all the compacts even after CIP. Alumina particles of slightly elongated shape tended to be aligned with their largest face normal to the direction of applied pressure in the uniaxial pressing. Correspondingly, the shrinkage during sintering was always larger in the direction parallel to uniaxial pressing as compared to that normal to it. Other conventional characterization methods including scanning electron microscopy (SEM) and powder X-ray diffraction failed to reveal the presence of a unique anisotropic packing structure.

[Received November 28, 1997; Accepted June 19, 1998]
\end{abstract}

Key-words : Alumina, Compact, Sintering, Deformation, Orientation, Liquid immersion method, Anisotropic packing structure

\section{1. 緒 言}

セラミックスの製造では，成形体と焼結体の形状が相似形に ならないこと,すなわち焼成時の変形が大きな技術的課題と なっている，それは変形した焼結体を所望の製品形状とするの に，ダイヤモンド工具等による修正加工を要し，これがセラ ミックス製品の大幅なコスト上昇，したがってその普及を著し く阻害する要因となるからである。変形原因には成形体中の粉 体充填密度の変動とともに，粉体粒子の配向が指摘されてい る1) 3)。 しかし，加圧成形法によるセラミックスでは多くの 研究にもかかわらず4) 8), 成形体中の粉体粒子の配向がわず かで，またその適切な評価技術も不備なため，変形原因には不 明な点が多い

著者らは成形体中の粉体粒子充填状態を調べるための新規評 価法を開発し，セラミックス製造プロセスに抢ける巨大欠陥の 生成, 内部応力の発生等種々の複雑な現象の研究に適用してき た (1),2),9～11)。この方法は成形体や成形体中の粒子充塤構造や 焼結体の微構造を，光学顕微鏡の透過モードで調べるものであ り，破壊源の形成や構造の異方性等の評価に抢いて，その能力 は従来の手法をはるかに超える。したがって本手法は成形プロ セス-成形体構造一焼結体構造-特性（変形）の関係について, 系統的かつ直接的な検討を初めて可能にすると期待できる。実 際，最近ではこの方法は顆粒やそのプレス成形体の構造評価用 として普及し始めている12)。しかしながら，これを加圧成形 体の構造異方性と焼結時の収縮異方性の関係の調査へ適用した 例はない.

本研究では, セラミックスの製造の代表例として, アルミナ 粉末の加圧成形プロセスを取り上げ，上述の新規評価法により 成形プロセスー成形体構造一焼結時の変形一焼結体構造の関係を 系統的に調べ，焼結時の変形原因を具体的に示す．ここで用い る原料粉体は一般の工業用のものであり，末た成形法もセラ ミックス製造で最も一般的なものである. したがって, 本研究 の成果はセラミックスの焼成変形の抑制と, ニヤネットシェイ プ化への実現へ大いに貢献すると期待される.

\section{2. 実 験}

試料粉体には市販の低ソーダアルミナ（160SG-1, 昭和電 工製)，バインダーにはPVA (PVA105，クラレ製）を用い た. まず, アルミナに等量の蒸留水, 及び 2 mass\%の PVA を加え, アトリションミルで $1 \mathrm{~h}$ 混合してスラリーとし，これ をスプレードライヤーにより顆粒とした。この顆粒を種々の圧 力 $(10 \sim 100 \mathrm{MPa})$ で一軸成形し, 更に冷間等方圧成形 (CIP, $100 \mathrm{MPa}$ )を行って直径 $10 \mathrm{~mm} \times$ 厚さ 4〜 $5 \mathrm{~mm}$ のペレット状 の成形体とした.この成形体から, 一軸加圧の方向に平行（以 後 $\mathrm{H}$ 軸と記載) 及び直交方向（以後, $\mathrm{D}$ 軸之記載）に, 長さ 2 $3 \mathrm{~mm}$ 程度の試料を切り出し, それぞれについて $1400^{\circ} \mathrm{C}$ ま での焼結収縮曲線（昇温速度 $10^{\circ} \mathrm{C} / \mathrm{min}$ ) を熱膨張計（TMA50 ，島津製作所製）で測定した。また，焼結体作製のため， ペレットを温度 $1550^{\circ} \mathrm{C}$ 及び $1600^{\circ} \mathrm{C}, 2 \mathrm{~h}$ 大気中で焼成した。こ の際の収縮率を, 焼成前後のペレットの寸法変化から求めた。 成形体及び焼結体の構造評価は光学影微鏡の透過モード観察及 び走查型電子顕微鏡（SEM）観察で行った。成形体試料の光 学顕微鏡による評価では, 試料を厚み $0.1 \mathrm{~mm}$ 程度の薄片と し，これにヨウ化メチレン（屈折率：1.74）を含浸後, 通常光 及び直交偏光の透過光モードでの観察を行った. SEM 観察で は，各試料の破断面に金をスパッターした。

\section{3. 結 果}

図 1 は一軸成形圧が成形体の相対密度に及ぼす影響である。 一軸成形後の成形体の相対密度は成形圧の増加々ともに著しく 増している。しかし， CIP 後のものは，一軸加王時の圧力之 ともにわずかに増加する程度である。

図 2 は CIP $(100 \mathrm{MPa})$ 時の成形体の各軸方向での収縮率に 及ぼす一軸成形圧の影響を示す，収縮率は，すべての条件で $\mathrm{D}$ 軸方向が $\mathrm{H}$ 軸より大きい。 なたそれらの間の収縮率の差は， 一軸成形王が低いときには大きいが，その増加とともに著しく 減少する。更に, 両方向での収縮率の比は一軸成形王の増加上 ともに増加する傾向が認められる。一軸成形王が CIP 王と同 じであると， $\mathrm{H}$ 軸方向の収縮は起きず，D 軸方向の収縮のみ が認められる。以上の上小り一軸成形体では，粉体粒子の充填 


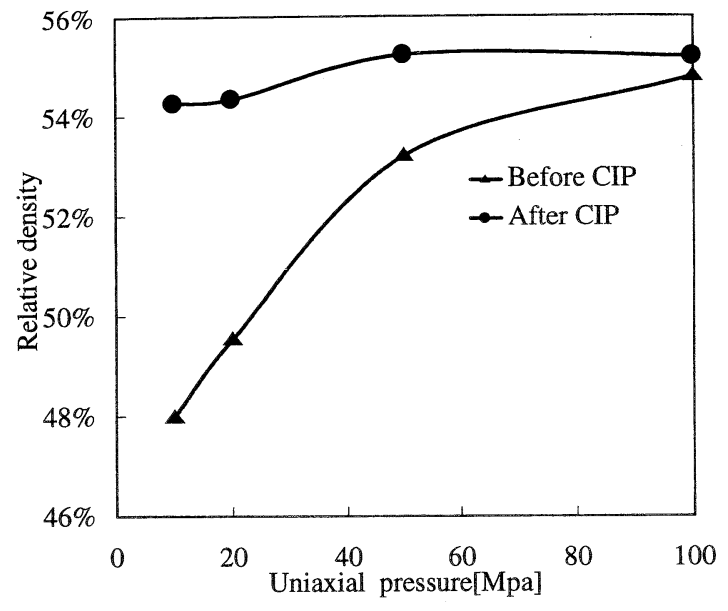

Fig. 1. Effect of uniaxial pressure on relative density before CIP and after CIP.

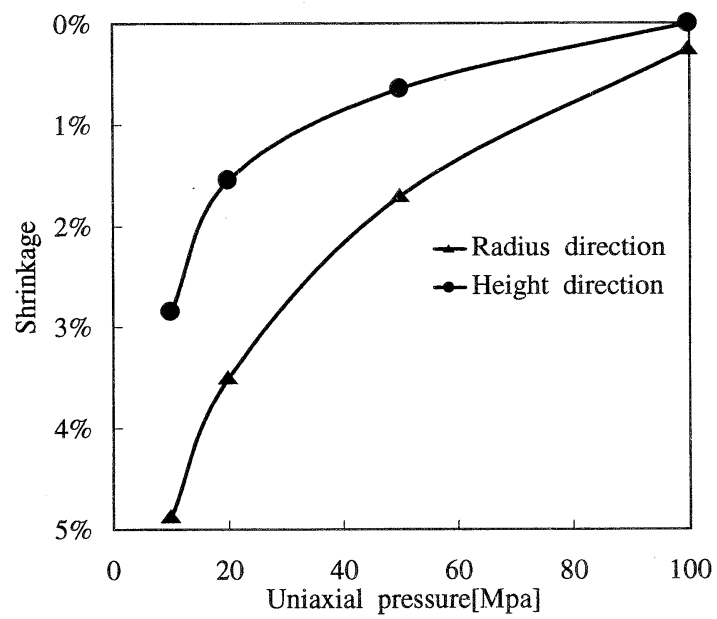

Fig. 2. Effect of uniaxial pressure on CIPing shrinkage of compacts in radius and height direction.

構造は明らかに異方的であり，それをCIP 処理する際には， $\mathrm{D}$ 軸方向，すなわち一軸成形時の圧力印加方向に垂直方向に 大きく収縮し，その方向での粒子間の距離が優先的に短縮され る.な押，粉末 X 線回折法により CIP 成形体中の両軸方向で の粒子配向を検討したが，いずれも同様の回折パターンを示 し，差異は認められなかった。

図 3 は一軸加圧と CIP 加圧がともに $100 \mathrm{MPa}$ の成形体につ いての，両軸方向での昇温時の収縮率の变化である。試料寸法 は両方向とも温度 $1000^{\circ} \mathrm{C}$ 程度までは, 温度上昇とともに熱膨 張によりわずかながら単調に増加するが， $1000^{\circ} \mathrm{C}$ 付近から減 少し始める。収縮は，測定最高温度の $1400^{\circ} \mathrm{C}$ ま $\mathrm{H}$ 軸方向が $\mathrm{D}$ 軸方向より常にやや大きい，同様の結果は, ペレットから の切り出し位置の異なる試料について数十回の実験で常に認め られた．また，それらの結果の変動も極めてわずかであった。 したがって，この収縮率の違いは明らかに粒子充填構造の異方

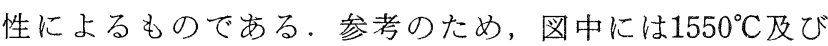
$1600^{\circ} \mathrm{C}, 2 \mathrm{~h}$ 焼結後の收縮率も示したが，それらでも $\mathrm{D}$ 軸方向 と $\mathrm{H}$ 軸方向の間に収縮率の違いが認められる。な打図中の点 線は，収縮が等方的に起きると考えて，成形体と焼結体の密度 から求めた収縮率 (17.7\%) である。この理論值は実測值の中 間に入っている。

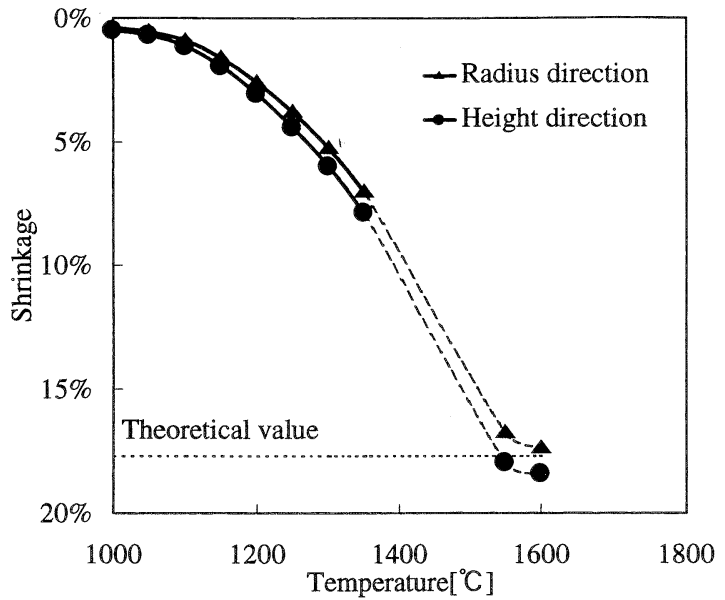

Fig. 3. Effect of sintering temperature on sintering shrinkage in radius and height direction.

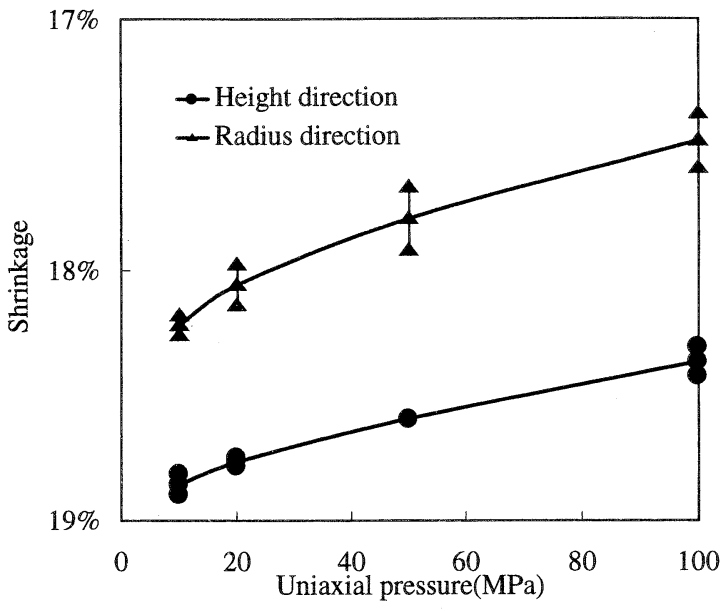

Fig. 4. Effect of uniaxial pressure on shrinkage of the bodies sintered at $1600^{\circ} \mathrm{C} / 2 \mathrm{~h}$ in radius and height direction.

図 4 は一軸成形圧が $\mathrm{CIP}$ 成形体の $1600^{\circ} \mathrm{C}$ 焼結後の両軸方向 における収縮率に及ぼす影響である。これらの結果でも，収縮 率は $\mathrm{H}$ 軸方向が $\mathrm{D}$ 軸方向より常に大きい。 また, 一軸成形压 の増加（すなわち成形体密度の増加）々ともに，收縮率自体の 値は減少する傾向にあるが，両軸に扔ける收縮率の比は大きく なる。

図 5 は収縮率比の温度変化に及ほす一軸成形圧の影響であ る. 同一の焼結温度条件下では, 収縮率比は一軸成形圧の上昇 とともに増加する。 また，すべての試料に扔いて，収縮率比は 焼結温度の上昇とともに減少する。すなわち焼結の初期では $\mathrm{H}$ 軸方向の収縮が優先しておき, 温度が更に增すと $\mathrm{D}$ 軸方向 の収縮が進む。繳密化が完了した埊結体では，一軸成形圧 100 MPaにおける収縮率比は約1.06である。すなわっ，寸法に拉 いて $6 \%$ 程度の歪みが生じる.

図 6 は CIP 成形体 (1 次成形王 $100 \mathrm{MPa}$ ) の $\mathrm{H}$ 軸方向 (a) 及 び $\mathrm{D}$ 軸方向 $(\mathrm{b})$ からの通常光による䫒微鏡写真である. $\mathrm{H}$ 軸方 向からの観察では，顆粒はほほ円形を保ってつぶれている。

$\mathrm{D}$ 軸方向からの観察では, 顆粒はその長軸を一軸プレス方向 とは直角方向に楕円形につぶれている.

図 7 は脱バインダー $\left(1050^{\circ} \mathrm{C}, 2 \mathrm{~h}\right)$ 後の CIP 成形体 (1 次成 形E100 MPa）についての H 軸方向, 及び D 軸方向からの直 


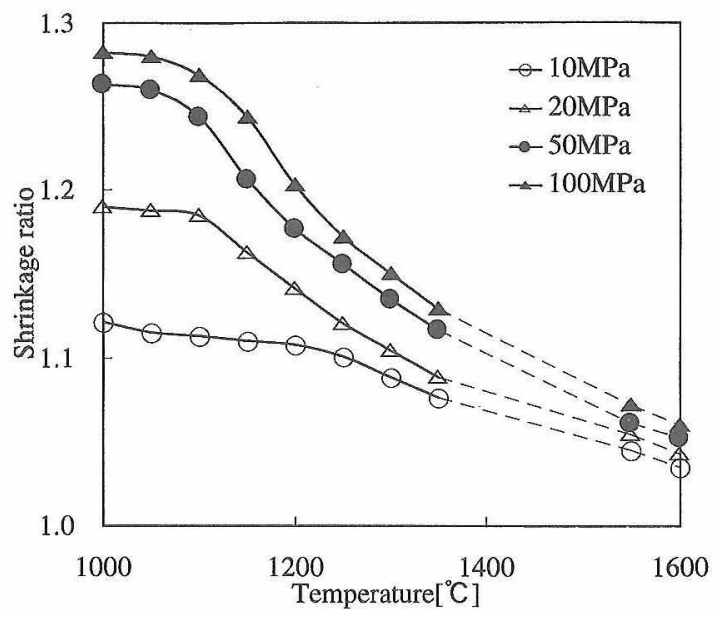

Fig. 5. Effect of sintering temperature on shrinkage ratio (shrinkage ratio of height direction to radius direction) at uniaxial pressure $10 \mathrm{MPa}, 20 \mathrm{MPa}, 50 \mathrm{MPa}, 100 \mathrm{MPa}$.
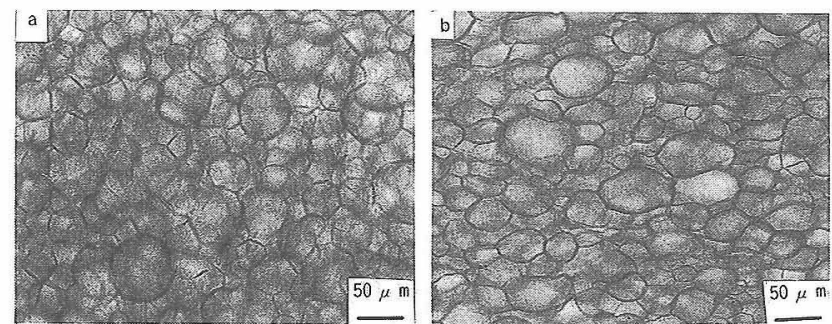

Fig. 6. Micrographs at normal optical mode for compacts. (a) a view from height direction, (b) a view from radius direction.
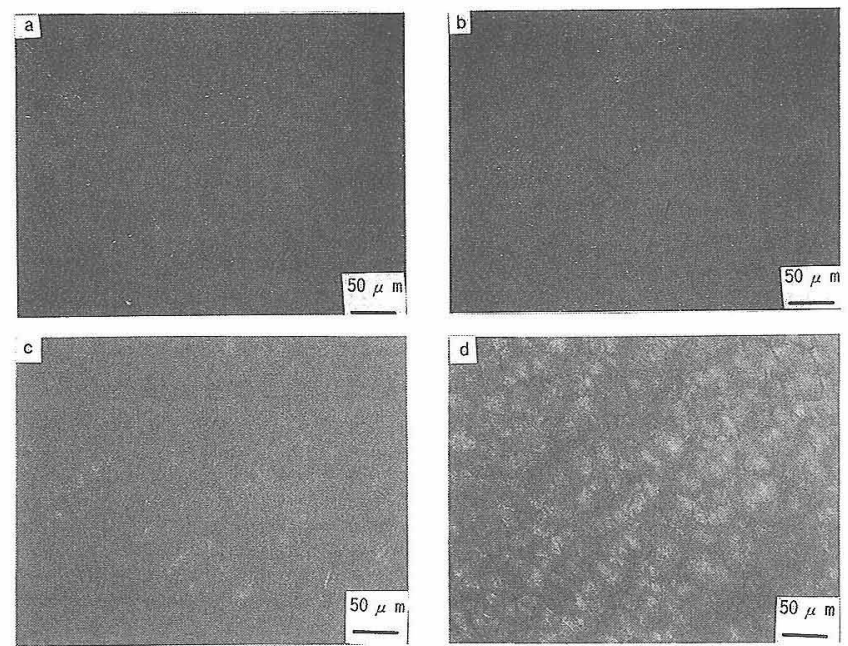

Fig. 7. Polarized light micrographs for compacts after binder removal. (a) a view from height direction, at $0^{\circ}$, (b) a view from height direction, at $45^{\circ}$, (c) a view from radius direction, at $0^{\circ}$, (d) a view from radius direction, at $45^{\circ}$.

交ニコルによる偏光顕微鏡写真である，H軸方向からの観察 では，観察視野は常に暗く，また試料の回転 $\left(a: 0^{\circ}, b: 45^{\circ}\right)$ とともに目立った変化は生じない。これは試料が $\mathrm{H}$ 軸に垂直 な面内では光学的に等方的なことを意味し，アルミナ粒子がこ の面内に不規則に並ぶことを示す．D軸方向からの同様の観 察では，試料は回転角 45 度ごとに明暗の变化を繰り返した
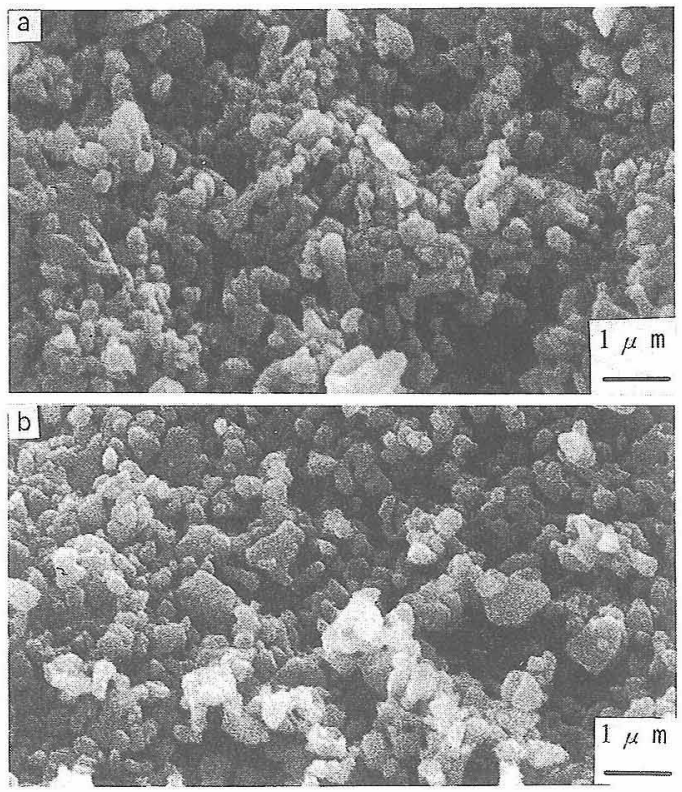

Fig. 8. SEM micrographs for compact. (a) a view from height direction, (b) a view from radius direction.

$\left(c: 0^{\circ}, d: 45^{\circ}\right)$ 。これは，アルミナ粒子が $\mathrm{D}$ 軸に垂直な面内 では配向していることを示すものである。なお，両試料中に は，微細な点状の明るい点が認められるが，それらは粗大なア ルミナ粒子である。

図 8 は成形体（一軸成形压100 MPa）の H 軸方向 (a)及び D 軸方向 (b) の断面についての SEM 写真で岁る。この場合に は，両試料において微細な粒子が充填している様子が局所的に は細部まで観察できる。しかし，全体的な粒子充垻構造につい ては，両者間に顕著な差が認められず，したがってこの観察方 法では，その両軸方向での構造の違いを認めるのは極めて困難 である。

\section{4. 考 察}

本研究では，一軸加圧-CIP 成形体中において，内部の粉体 粒子はやや配向して異方的に充埧されており，これはCIP 処 理によっても完全には解消されないことが明らかとなった。こ れは著者らの従来の報告(10),11),13),14) と同様である。この構造は 今回の評価法でのみ明らかとなるものであり，今回の研究です 示したとおり SEM 観察など従来の評価手法では解明できない ものである。おた，今回の試料は滑剤等を含まず，工業的な系 より粒子相互の移動が困難であり，粒子配向の起き難いもので ある。したがって，今回の結果は当初の目的ど抢り，セラミッ クスの基礎研究に抢汀る新たな局面を開くと期待される.

一般に焼結時の収縮異方性を生じる原因には，粒子配向とと もに成形体中の密度分布が考えられる。しかし，本研究では試 料のどの部分から切り出した試料でも同様の結果が得られたこ とから，成形体中の粒子充埧密度は均一と判断される。した がって本研究で認められた焼結収縮の異方性が密度分布による ものではないことは確実であり，その原因は粒子の配向による むのである。

図 4 及び図 5 では，一軸成形圧の增加とともに焼結時の収 縮率比が增す。一軸成形では, 压力の増加とともに成形体中の 粒子充填の異方性が増すのは当然であり，したがって CIP 処 理後でも成形体構造の異方性が増すのは当然である。また更 に，一軸成形压の増加とともに，焼結時の変形異方性が增すこ 
とも理解できる。な抢，一軸成形圧と粒子配向性について，更 に定量的な解析を行うことは非常に興味深いが，それには評価 法の一層の改善が必要である。したがって，これについては今 後の検討課題とする.

図 5 に抢いて, 焼結時の収縮率比が焼結の進行とともに変 化するのは工業的にも非常に興味深い，一般に成形体では，そ の各部分の粒子配向が異なると考えられるが，この結果はその 焼結時に各部分の収縮が同様に進行せず，部分間にある種の歪 みを生じつつ進むことを示唆する，その間に，それらの部分間 には応力が発生すると考えられ，これが焼結時の変形だけでな く，㫿の形成等にも影響すると予想される.したがって，こ の現象はセラミックス製品の品質にもかかわる課題を含んでい る. 今後その詳細な検討が必要である.

粉体粒子の配向構造が焼結性に及ぼす影響については，今日 でもメカニズム的には明確ではないが，Uematsu ら ${ }^{2)}$ はアルミ ナ射出成形体に打ける円柱状のスプル一部に打いて同様の結果 を報告している。すな水ちスプル一部では粒子は明確な配向構 造をもち，やや延伸したアルミナ粒子がその長手方向を成形時 の流れ方向に平行に配列している。焼結時の収縮は流れ方向で は，それに直角方向より少ない結果が得られている.

このような収縮の異方性を生じる可能性として，粒子間の接 触点が長手方向では，それと直角方向より少ないことが指摘さ れている2).なぜなら，焼結時に収縮するのは粒子間の粒界の 物質が拡散でネック領域に輸送されるためであるが，長手方向 では成形体単位長さ当たりの粒界数が少なく, 収縮を生じる個 所が少ないためである，加圧成形体の場合には，粉体粒子の配 向は射出成形体ほどは顕著ではないが，同様の説明が可能であ る.しかし，この問題については理論面も含めて今後の検討課 題である。

今回の研究では焼結体の微構造については検討していない が，射出成形体では焼結後に粒子配向構造が一層顕著となるこ とが明らかにされている3゙.したがってその場合には焼結は成 形体の異方性を更に増大させる作用をもち，それを解消するも のではない，同様のことは本系でも生じると考えられる，した がって, 成形体構造の均一化は, 均質なセラミックスをつくる うえで非常に重要であり, 今回の研究はセラミックスの製造に 打ける成形の重要性を改めて示すものである。なお, 微構造形 成と粉体充填構造との関係についても従来十分には解明されて
おらず，この点も今後の検討課題である。

\section{5. 結 論}

一軸成形-CIP 成形体における粒子の配向構造は, 焼結時の 変形を抢こす原因であることが明らかになった，一軸成形圧の 増加とともに，その後の CIP 処理による配向構造の破壊が一 層困難となる．このような配向構造を従来法で検出するのは極 めて困難であり，これがプロセス研究に打ける障害の原因で あった. 本研究では, 多数の工業的に重要かつ材料科学的に興 味深い現象を多数指摘したが, それらはセラミックスの研究領 域拡大に貢献すると期待される.

謝辞 本研究は, 平成 7 年度新エネルギー・産業技術総合 開発機構 (NEDO) 提案公募型・最先端分野研究開発制度で行わ れたものである。

\section{文献}

1) K. Uematsu, H. Ito, S. Ohsaka, H. Takahashi, N. Shinohara and M. Okumiya, J. Am. Ceram. Soc., 78, 3107-09 (1995).

2) K. Uematsu, S. Ohsaka, N. Shinohara and M. Okumiya, J. Am. Ceram. Soc., 80, 1313-15 (1997).

3) F. V. Dimarcello, P. L. Key and J. C. Williams, J. Am. Ceram. Soc., 55, 509-14 (1972).

4) R. A. Youshaw and J. W. Halloran, Am. Ceram. Soc. Bull., 61, 227-30 (1982).

5) R. A. DiMilla and J. S. Reed, Am. Ceram. Soc. Bull., 62, 48488 (1983).

6) J. A. Brewer, R. H. Moore and J. S. Reed, Am. Ceram. Soc. Bull., 60, 212-15, 220 (1981).

7) B. D. Mosser, J. S. Reed and J. R. Varner, Am. Ceram. Soc. Bull., 71, 105-09 (1992).

8) H. Tanaka, A. Sakamoto, Y. Nagao, S. Fukai, N. Uchida and K. Uematsu, J. Am. Ceram. Soc., 77, 3077-80 (1994).

9）植松敬三，金 鎮映，加藤善二，内田 希，斉藤勝一，七ラ ミックス論文誌，98, 515-16 (1990).

10) K. Uematsu, Powder Technol., 88, 291-98 (1996).

11) K. Uematsu, H. Ito, Y. Zhang and N. Uchida, "Ceram. Trans.," Vol. 54, Am. Ceram. Soc. (1995) pp. 83-89.

12) Y.Okumoto, K. Atagi, Y. Kondo and K. Ishizaki, J. Ceram Soc. Japan, 105, 771-74 (1997).

13) K. Uematsu, H. Tanaka, Y. Zhang and N. Uchida, J. Ceram. Soc. Japan, 101, 1400-03 (1993).

14) K. Uematsu, S. Ohsaka, H. Takahashi, N. Shinohara, M. Okumiya, Y. Yokota, K. Tamiya, H.Takahashi and T. Ohira, J. Eur. Ceram. Soc., 17, 177-81 (1997). 